\section{OPEN ACCESS}

Edited by:

Xiting Liu,

Ocean University of China, China

Reviewed by: Xinxin $L i$,

Southern University of Science and

Technology, China

Zou Xinqing,

Nanjing University, China

*Correspondence:

Rui Zhang

rzhang_838@163.com

Tiegang $L$

tgli@fio.org.cn

Specialty section:

This article was submitted to

Marine Geoscience,

a section of the journal

Frontiers in Earth Science

Received: 17 October 2021

Accepted: 28 December 2021

Published: 31 January 2022

Citation:

Wang $Y$, Yang J, Wang G, Zhang $Y$,

Zhang $R, L i T$, Russell J, Wang J,

Wang $X$, Zhang $F$, Song $Y, Y u X, H u J$,

Liu Z, Guan M and Han Q (2022)

Source Identification of brGDGTs in the

Surface Sediments of the East

China Sea.

Front. Earth Sci. 9:796539.

doi: 10.3389/feart.2021.796539

\title{
Source Identification of brGDGTs in the Surface Sediments of the East China Sea
}

\begin{abstract}
Yipeng Wang 1,2,3, Jialei Yang ${ }^{3}$, Guichen Wang ${ }^{4}$, Yinyi Zhang ${ }^{4}$, Rui Zhang ${ }^{1,2,3,5 *}$, Tiegang $L_{i}^{6,7,8 *}$, James Russell ${ }^{5}$, Jiayue Wang $^{3}$, Xinling Wang ${ }^{3}$, Fan Zhang $^{9}$, Yuehua Song ${ }^{3}$, Xiaoxiao $\mathrm{Yu}^{10}$, Junjie $\mathrm{Hu}^{3}$, Zhiyong $\mathrm{Liu}^{11}$, Minglei Guan ${ }^{3}$ and Qi Han ${ }^{12}$

${ }^{1}$ Co-Innovation Center of Jiangsu Marine Bio-industry Technology, Jiangsu Ocean University, Lianyungang, China, ${ }^{2}$ Jiangsu Key Laboratory of Marine Bioresources and Environment, Jiangsu Ocean University, Lianyungang, China, ${ }^{3}$ School of Geodesy and Geomatics Engineering, Jiangsu Ocean University, Lianyungang, China, ${ }^{4}$ Lianyungang Meteorological Bureau, Lianyungang, China, ${ }^{5}$ Department of Earth, Environmental, and Planetary Sciences, Brown University, Providence, RI, United States, ${ }^{6}$ First Institute of Oceanography, Ministry of Natural Resources, Qingdao, China, ' Laboratory for Marine Geology, Qingdao National Laboratory for Marine Science and Technology, Qingdao, China, ${ }^{8}$ University of Chinese Academy of Sciences, Beijing, China, ${ }^{9}$ Department of Chemical Engineering, Jiangsu Ocean University, Lianyungang, China, ${ }^{10}$ State Key Laboratory of Isotope Geochemistry, Guangzhou Institute of Geochemistry, Chinese Academy of Sciences, Guangzhou, China, ${ }^{11}$ School of Radiation Medicine and Protection, Medicine College, Soochow University, Suzhou, China, ${ }^{12}$ School of Ocean Sciences, China University of Geosciences, Beijing, China
\end{abstract}

Branched glycerol dialkyl glycerol tetraethers (brGDGTs) are components of bacterial membranes in terrestrial soils, which are widely used in paleoenvironmental reconstruction in global terrestrial soils and marine sediments. In marine sediments, the mixed sources of brGDGTs complicate the applications of brGDGT-related indicators in reconstructing terrestrial environments. In this study, we reported the spatial distribution of brGDGTrelated indicators (MBT' $5 \mathrm{ME}, \mathrm{CBT}^{\prime} 5 \mathrm{ME}$, \#Ringstetra, and Illa/lla) in surface sediments from the East China Sea (ECS). MBT' $5 \mathrm{ME}$ and CBT' $5 \mathrm{ME}$ showed a stepped trend from the inner shelf to the outer shelf, and \#Ringstetra and $\sum$ IIla/ $\sum$ lla values in sediments of the ECS are distinct compared with those in the catchment soils, suggesting marine in situ production of brGDGTs. We also examined the existence of marine in situ brGDGTs and quantitatively determined the contributions of terrestrial and in situ production of brGDGTs. This study reported mixed sources of soil-derived brGDGTs were dominant, and marine in situ brGDGTs were overprinted. Our results indicate that there were predominantly marine in situ brGDGTs (avg. $60.5 \pm 5.5 \%$ ) in the outer shelf due to the weak riverine transportation and were characterized by high \#Ringstetra and IIla/lla.

Keywords: brGDGTs and their isomers, marginal sea, marine in situ brGDGTs, soil, Changjiang river

\section{INTRODUCTION}

Branched glycerol dialkyl glycerol tetraethers (brGDGTs) are membrane-spanning lipids found in bacteria with different degrees of methylation and cyclization. They are widespread in soil, peat, rivers, lakes, and marine sediments (Hopmans et al., 2004; Blaga et al., 2009; Kim et al., 2012). The methylation index of branched tetraethers (MBT) and the cyclization ratio of branched tetraethers (CBT) are found to have substantial correlations with mean annual air temperature (MAAT) and $\mathrm{pH}$, and the associations are used to recreate paleoenvironments in worldwide soils and peat (Weijers et al., 2007). However, some studies have reported the significant differences when applied to 
estimated MAATs by global soil- and peat-based brGDGT calibrations due to the source and seasonal differences in regional coasts (Coffinet et al., 2014; Dong et al., 2014; Ge et al., 2014; Zell et al., 2014). The limitations of the global calibrations promote the development of local regional temperature calibrations. For example, compared with local regional calibrations, global calibration overestimated MAAT by about $4^{\circ} \mathrm{C}$ in warm and humid acid soil regions (Yamamoto et al., 2016) but underestimated about $4-9^{\circ} \mathrm{C}$ MAAT in semiarid and arid region alkaline soils (Yang et al., 2014). Besides, improved chromatographic methods can be used to separate 5-, 6-, and 7-methyl isomers, and the MAAT, pH calibrations have been improved by 5 -methyl brGDGTs (De Jonge et al., 2013; De Jonge et al., 2014; Liu et al., 2021). Moreover, Russell et al. (2018a), 2018b developed a new temperature calibration method for MAAT for use in the aquatic environment, based on the $\mathrm{MBT}^{\prime}$ 5ME-empirical model and a multivariate regression of brGDGT fractional abundances on temperature.

During previous reports, brGDGTs in marine sediments were considered to be particular tracers for terrestrial soil organic matter (Hopmans et al., 2004). Recent research has reported that the distributions of brGDGTs in marine sediments and continental soils are distinct (Hopmans et al., 2004; Peterse et al., 2009; Sparkes et al., 2015). Sinninghe Damsté (2016) established the average number of cyclopentane moieties in tetramethylated brGDGTs (\#Ringstetra), and reported that \#Ringstetra value of marine-derived brGDGTs $(>0.7)$ is higher than that of the soil-derived brGDGTs $(<0.7)$. This index has been effectively utilized to reconstruct the sources of brGDGTs in the North Sea Basin and Baltic Sea (Crampton-Flood et al., 2018; Warden et al., 2018). Additionally, the ratio of hexamethylated to pentamethylated brGDGT ( $\sum \mathrm{III} / \sum \mathrm{II}$ ) has been used to trace the sources of brGDGTs in marine sediments. The $\sum$ IIIa/ $\sum$ IIa value less than 0.59 in over $90 \%$ of global soil, varies between 0.59 and 0.9 in nearshore marine sediments, and above 0.9 in the deep sea (Xiao et al., 2016). Some simulations also suggested in situ lipid production in the lake water column (Martínez-Sosa et al., 2020). Additionally, these investigations demonstrate the existence of water or marine in situ production of brGDGTs, which had effects on paleoclimate reconstructions.

BrGDGTs and related indicators were used for paleoclimate reconstructions in the ECS (Zhu et al., 2011; Ge et al., 2016; Zhang et al., 2018; Duan et al., 2019; Zhang et al., 2020). In previous studies, the Yangtze River subaqueous delta is mainly composed of sediment discharged from the Yangtze River, and most finer sediments escape the river mouth and disperse further seaward (liu et al., 2006). Zhu et al. (2011) reported that the MBT/CBTderived MAAT reflected the temperature of the upper basin $\left(4-10^{\circ} \mathrm{C}\right)$, rather than the mid-lower basin $\left(14-18^{\circ} \mathrm{C}\right)$ in ECS surface sediments. And Ge et al. (2016) established MBT/CBTderived MAAT was more likely to reflect mid-lower basin temperature. Zhang et al. (2018) reported a strong correlation between brGDGT records and historical flood events. The ZheMin coastal mud area was limited to the offshore area and mainly affected by the source material of the Yangtze River, and local rivers in Zhejiang-Fujian. However, different amounts of Yangtze
River sediments moved south in different periods, and the source of sediments in the outer shelf remains to be clarified in future studies (Liu et al., 2018). Due to mixed sources of sedimentary deposits and the complexity of hydrodynamic processes, the brGDGT-related indicators are used to reveal different climatic information in the ECS. In addition, Cao et al. (2020) and Liu et al. (2021) attempted to constrain the source attribution of mixed brGDGTs in the ECS sediments. According to these research studies, brGDGTs are predominantly derived from continental soil erosion. Recently, it is challenged by the potential existence of marine in situ brGDGTs in ECS sediments (Duan et al., 2019; Zhang et al., 2020). However, the source attribution of different brGDGT sources in marginal ECS remains poorly constrained, which is significant for paleoclimatic reconstruction. The purpose of this study was to determine the source of brGDGTs and investigate the link between the native environment of brGDGTs and their indicators.

\section{MATERIALS AND METHODS}

\section{Study Area}

The study areas were located in the ECS (Figure 1), a typical river-dominated continental margin sea that has been deeply influenced by riverine inputs from terrestrial soil in the Yangtze River (YR) catchments. The ECS received about $12 \mathrm{Mt} / \mathrm{yr}$ of organic matter $(\mathrm{OM})$ as the largest continental margin in the Western Pacific realm (Wu et al., 2003). The muddy areas on the Yangtze River subaqueous delta and the Zhe-Min coastal mud area are formed by terrestrial inputs. As a result, the ECS shelf is an important target for paleoclimate reconstruction and understanding the role of the continental marginal sea in global carbon cycling.

\section{Sample Collection and Analysis}

Between 2013 and 2015, surface sediments $(0-2 \mathrm{~cm})$ were collected from 53 study locations in the ECS using a box corer (Figure 1). Samples were immediately placed in pre-cleaned polyethylene bags, sealed, and stored in a $-20^{\circ} \mathrm{C}$ freezer until further analysis. Samples were freeze-dried for more than $48 \mathrm{~h}$ in a Christ Delta 1-24 LSC Laboratory freeze dryer (Christ, Germany). The dried samples were ground using a precleaned agate mortar and pestle for further analysis.

\section{Lipid Extraction and GDGT Analysis}

Lipid extraction and GDGT analysis were conducted following the protocol described by Hopmans et al. (2016) and Zhang et al. (2018). Then $5 \mathrm{~g}$ of freeze-dried samples were weighed, ground, mixed with a quantified standard ( $\mathrm{C}_{46} \mathrm{GDGT}$ ) (Huguet et al., 2006), and analyzed using an Agilent 1200 high-performance liquid chromatography system coupled to an Agilent 6460A triple-quadrupole mass spectrometer (HPLC-MS/MS) with atmospheric pressure chemical ionization (APCI) (Hopmans et al., 2004; Hopmans et al., 2016). The GDGTs were separated using two silica columns in tandem at $40^{\circ} \mathrm{C}$. The elution gradients were $n$-hexane/ethyl acetate $(84: 16 ; v: v)$ for 


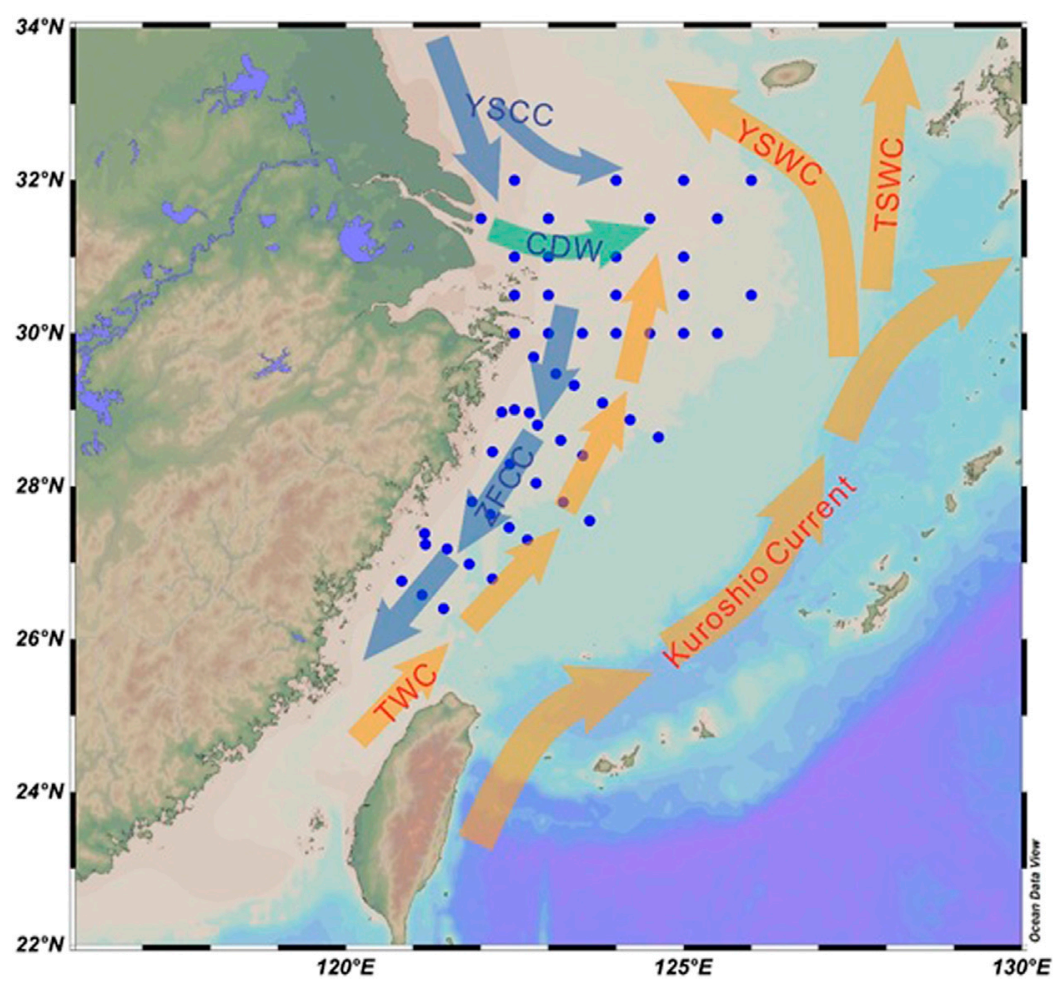

FIGURE 1 | Location of surface sediment samples in the East China Sea. ZFCC: Zhejiang and Fujian Coastal Current; TWC: Taiwan Warm Current; YSCC: Yellow Sea Coastal Current; YSWC: Yellow Sea Warm Current; TSWC: Tsushima Warm Current; CDW: Changjiang diluted water.

the first 5 min, n-hexane/ethyl acetate (82:18; v:v) for another $60 \mathrm{~min}$, and then ethyl acetate for $21 \mathrm{~min}$ and kept for $4 \mathrm{~min}$, followed by n-hexane/ethyl acetate (84:16; v:v) for $30 \mathrm{~min}$ at a flow rate of $0.2 \mathrm{ml} / \mathrm{min}$. The $\mathrm{MS}$ conditions were given as follows: nebulizer at $60 \mathrm{psi}$, vaporizer at $400^{\circ} \mathrm{C}, \mathrm{N}_{2}$ flow at $6 \mathrm{~L} /$ min and temperature at $200^{\circ} \mathrm{C}$, the capillary voltage $3500 \mathrm{~V}$, and corona current at $5 \mu \mathrm{A}(3200 \mathrm{~V})$. Selected ion monitoring (SIM) was used for monitoring at $\mathrm{m} / \mathrm{z} 1,292,1,050,1,048$, $1,046,1,036,1,034,1,032,1,022,1,020,1,018$, and 744 . The quantification of GDGTs was performed by comparing the peak area of each compound with that of the C46 GDGT internal standard. The average relative standard deviation (RSD\%) was lower than $10 \%$.

\section{Calculation of GDGT-Related Proxies}

BIT (a ratio of the branched and isoprenoid tetraether) index was calculated according to Hopmans et al. (2004):

$$
\text { BIT }=\frac{\left(\mathrm{Ia}+\mathrm{IIa}+\mathrm{IIIa}+\mathrm{IIa}^{\prime}+\mathrm{IIIa}^{\prime}\right)}{\left(\mathrm{Ia}+\mathrm{IIa}+\mathrm{IIIa}+\mathrm{IIa}^{\prime}+\mathrm{IIIa}^{\prime}+\text { Cren }\right)} .
$$

$\mathrm{MBT}^{\prime} 5 \mathrm{ME}, \mathrm{CBT}^{\prime} 5 \mathrm{ME}$, and $\mathrm{pH}$ were calculated according to De Jonge et al. (2014):

$$
\begin{gathered}
\mathrm{MBT}_{5 \mathrm{ME}}^{\mathrm{C}}=\frac{(\mathrm{Ia}+\mathrm{Ib}+\mathrm{Ic})}{(\mathrm{Ia}+\mathrm{Ib}+\mathrm{Ic}+\mathrm{IIa}+\mathrm{IIb}+\mathrm{IIc}+\mathrm{IIIa})}, \\
\mathrm{CBT}_{5 \mathrm{ME}}^{\mathrm{C}}=-\log \frac{(\mathrm{Ib}+\mathrm{IIb})}{(\mathrm{Ia}+\mathrm{IIa})}, \text { and } \\
\mathrm{pH}=7.84-1.73 \times \mathrm{CBT}_{5 \mathrm{ME}}^{C}
\end{gathered}
$$

The weighted average number of cyclopentane moieties (\#Rings $_{\text {tetra }}$ ) was calculated for the tetramethylated brGDGTs according to Sinninghe Damsté (2016):

$$
\text { \#Rings }_{\text {tetra }}=\frac{(\mathrm{Ib}+2 \times \mathrm{Ic})}{(\mathrm{Ia}+\mathrm{Ib}+\mathrm{Ic})} .
$$

MAAT was calculated according to Russell et al. (2018):

$$
\begin{gathered}
\text { MAAT }=23.81-31.02 \times \mathrm{IIIa}-41.91 \times \mathrm{IIb}-51.59 \times \mathrm{IIb}^{\prime} \\
-24.70 \times \mathrm{IIa}+68.8 \times \mathrm{Ib} \text { and } \\
\text { MAAT }=-1.21+32.42 \times \mathrm{MBT}_{5 \mathrm{ME}}^{C} .
\end{gathered}
$$

IIIa/IIa as calculated according to Xiao et al. (2016):

$$
\frac{\sum \mathrm{IIIa}}{\sum \mathrm{IIa}}=\frac{\mathrm{IIIa}+\mathrm{IIIa}^{\prime}}{\mathrm{IIa}+\mathrm{IIa}^{\prime}}
$$




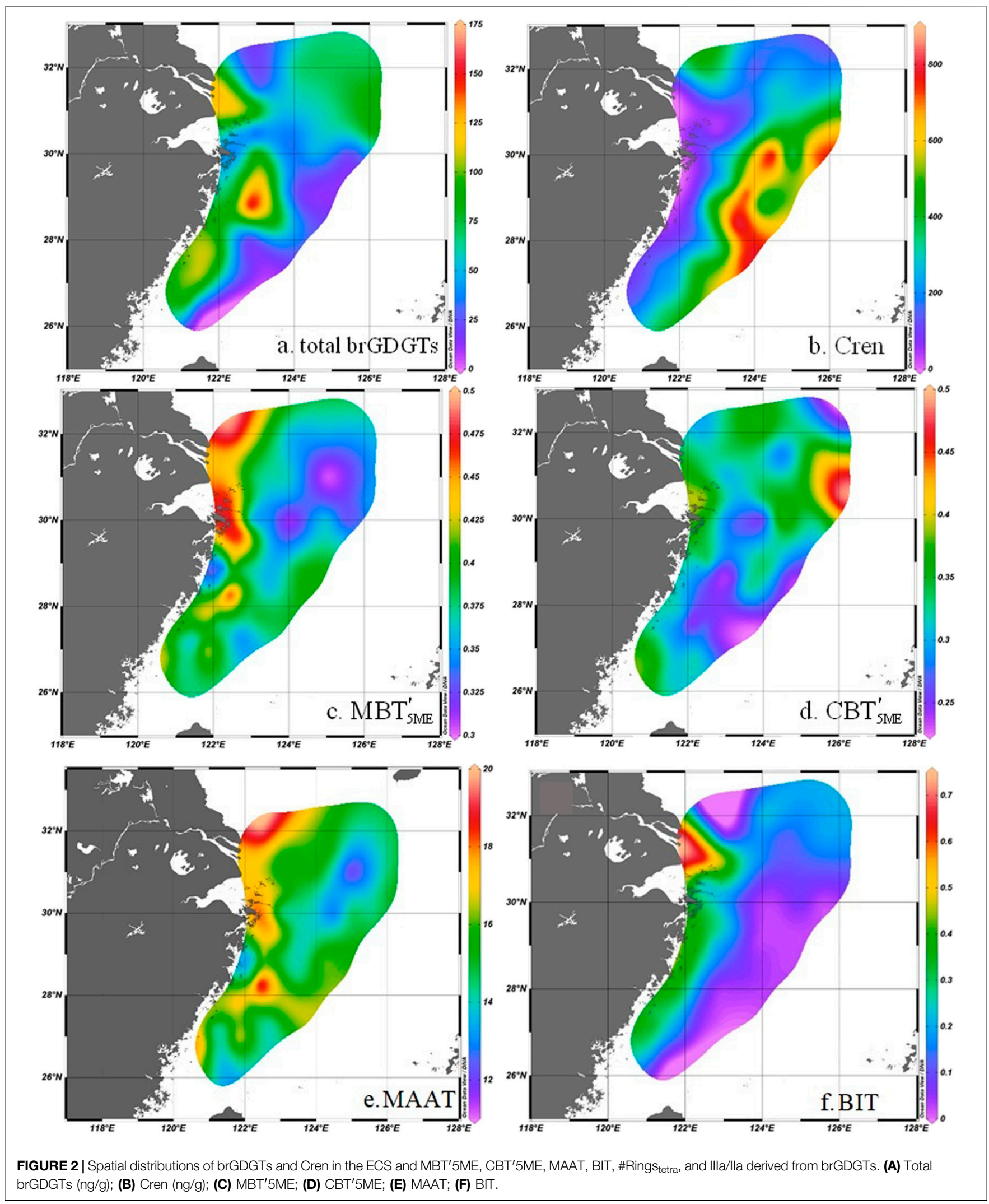




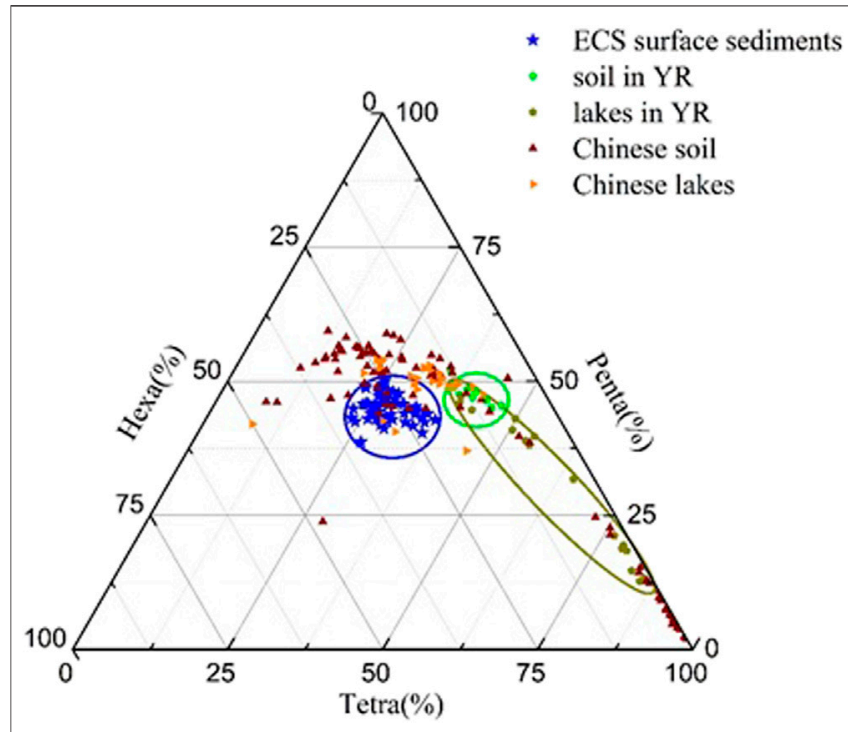

FIGURE 3 | Abundances of tetramethyl, pentamethyl, and hexamethyl brGDGTs of surface sediments of the ECS continental shelf, Chinese soil, Chinese lakes, lakes, and soils in the Yangtze River catchment (Xie et al., 2012; Yang et al., 2014; Dang et al., 2018).

\section{RESULTS}

\section{Spatial Distribution of brGDGTs and Crenarchaeol (Cren) in ECS Surface Sediments}

In ECS, the brGDGT contents in the sediments ranged from 19.7 ng/g to 158.7 ng/g (avg. 66.59 ng/g), as shown in Figure 2A. From the subaqueous delta of the Yangtze River and the Zhe-Min coastal mud area to the outer shelf, the brGDGT contents showed a decreasing trend with water depth. The Cren contents varied from $36.1 \mathrm{ng} / \mathrm{g}$ to $814.9 \mathrm{ng} / \mathrm{g}$ (avg. $312.15 \mathrm{ng} / \mathrm{g}$ ) in ECS (Figure 2B). In comparison with brGDGTs, the spatial distribution of Cren exhibited an opposite spatial distribution (Figure 2B).

In addition, the brGDGT contents were dominated by brGDGTs without cyclopentane moieties including brGDGTIa $(16.6 \pm 4.7 \%)$, IIa $(19.3 \pm 3.1 \%)$, II'a $^{\prime}(8.7 \pm 2.9 \%)$, IIIa $(11.3 \pm$ $4.5 \%)$, and III'a $(10.8 \pm 3.1 \%)$, which accounted for between 60.1 and $-70.2 \%$ of the total brGDGT content, while brGDGTs with 12 cyclopentane moieties accounted for between 29.8 and $39.9 \%$. Besides, tetra-, penta- , and hexamethyl-brGDGTs accounted for $32.3 \pm 1.3 \%, 46.3 \pm 1.2 \%$, and $26.4 \pm 1.1 \%$ of the total brGDGT content, respectively (Figure 3 ).

\section{brGDGT Proxies in ECS Surface Sediments}

In ECS sediments, the $\mathrm{MBT}^{\prime} 5 \mathrm{ME}$ value ranged between 0.30 and 0.48 (avg. $0.38 \pm 0.11$ ), and the $\mathrm{MBT}^{\prime} 5 \mathrm{ME}$ value showed a decreasing trend from the subaqueous delta of the Yangtze River and inner shelf to the outer shelf (Figure 2C). The $\mathrm{CBT}^{\prime}$
$5 \mathrm{ME}$ value ranged between 0.23 and 0.49 (avg. $0.31 \pm 0.13$, Figure 2D). Compared with the $\mathrm{CBT}^{\prime} 5 \mathrm{ME}$ in the inner shelf, the brGDGTs in the subaqueous delta of the Yangtze River showed stronger cyclization. The $\mathrm{CBT}^{\prime} 5 \mathrm{ME}$-derived $\mathrm{pH}$ ranged from 7.0 to 7.45 (avg. $7.3 \pm 0.2$ ) in the ECS. The calibration for MAAT by Russell et al. (2018a) ranged from $11.9^{\circ} \mathrm{C}$ to $19.7^{\circ} \mathrm{C}$ (avg. $15.4 \pm 2.4^{\circ} \mathrm{C}$, Figure 2E) and was consistent with the measured annual MAAT in mid-lower reaches of the Yangtze River $\left(14.7^{\circ} \mathrm{C}-16.9^{\circ} \mathrm{C}\right.$, avg. $\left.15.4 \pm 1.8^{\circ} \mathrm{C}\right)$ (Li et al., 2015). The MAAT based on $\mathrm{MBT}^{\prime} 5 \mathrm{ME}$ ranged from $8.6^{\circ} \mathrm{C}$ to $14.5^{\circ} \mathrm{C}$ (avg. $11.2 \pm 2.1^{\circ} \mathrm{C}$ ) and was $4^{\circ} \mathrm{C}$ lower than the measured annual MAAT in mid-lower reaches of the Yangtze River. The BIT values ranged from 0.02 to 0.71 (avg. $0.12 \pm$ 0.13 ), which showed a decreasing trend from the inner shelf to the outer shelf (Figure $\mathbf{2 F}$ ). The \#Rings tetra $_{\text {and IIIa/IIa values }}$ ranged from 0.40 to 0.79 (avg. $0.59 \pm 0.15$ ) and 0.35 to 0.78 (avg. $0.58 \pm 0.13$ ), respectively, which also showed an increasing trend from the inner shelf to the outer shelf (Figures 2G,H).

\section{DISCUSSION}

\section{Environment Significance of MAAT Based on brGDGTs in the ECS}

In comparison to the calibration (based on worldwide soil) for MAAT by De Jonge et al. (2014), the calibration (based on the aquatic environment) for MAAT by Russell et al. (2018a) had a lesser variance with the measured annual MAAT in the Yangtze River's mid-lower reaches. This finding was most likely attributable to the aquatic environment, yet Russell et al. (2018a)'s MAAT was still a deviation applied to ECS sediments. In the inner shelf, the MAAT was more consistent with the recorded air temperature in the midlower reaches of the Yangtze River (Supplementar Figure S1 in the Supplementary Materials). This supports the previous report that most of the riverine inputs deposited and accumulated to form the subaqueous delta and inner shelf (Liu et al., 2006). Therefore, the MAAT of the subaqueous delta-brGDGTs closely matched the recorded air temperature of mid-lower catchments of the Yangtze River. Compared with the inner shelf, the MAAT based on $\mathrm{MBT}^{\prime} 5 \mathrm{ME}$ in the outer shelf indicated a lower level temperature than the recorded air temperature in the mid-lower reaches of the Yangtze River. In membrane lipid simulations, decreasing the degree of methylation leads to a more ordered and compact membrane with reduced membrane fluidity, providing a mechanistic foundation for widespread observation from natural samples that the degree of methylation of brGDGTs decreases with increasing temperature (Naafs et al., 2021). This explains why marine sediments contained fewer tetramethylated brGDGTs than soil (Sinninghe Damsté., 2016). Moreover, the presence of marine in situ brGDGTs resulted in a lower degree of tetramethylation brGDGTs in marine sediments than in the soil. 

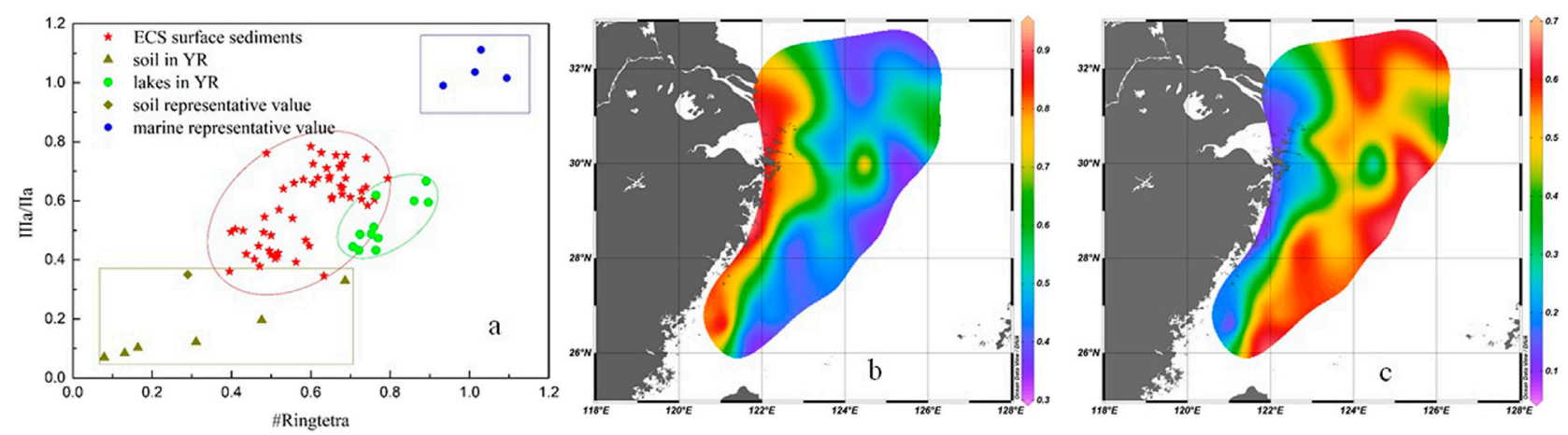

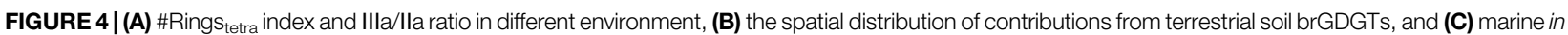
situ brGDGTs.

\section{Source Apportionment of brGDGTs in the ECS}

BIT was used to track terrestrial OM in the sediments, where brGDGTs originated from terrestrial soil (Hopmans et al., 2004; Weijers et al., 2007, Kim et al., 2012). The BIT value decreased offshore in ECS sediments, and the peak area was controlled by the Changjiang River. Although the BIT value did not take into account the in situ production of brGDGTs in the ECS, but it still indicated the influence of terrestrial materials in the large estuary. When compared to soil and lake sediments in the Yangtze River Basin, ECS surface sediments showed significant differences among tetra-, penta-, and hexamethylated brGDGTs (Figure 3) (Xie et al., 2012; Yang et al., 2014; Dang et al., 2018). This is consistent with findings from previous studies (Zhu et al., 2011; Sinninghe Damsté, 2016; Zhang et al., 2020). The fractional abundance of tetramethylated brGDGTs in ECS surface sediments was lower than the soil and lake sediments of the Yangtze River Basin, and the pentamethylated brGDGT level was higher. Furthermore, the majority of the brGDGTs in the ECS surface sediments were pentamethylated brGDGTs, whereas the soil contained mostly tetramethylated brGDGTs. This result represents the aquatic environment was smaller than the soils in our study area due to the degree of temperature difference, and the degree of methylation of brGDGTs decreases with increasing temperature. In ECS sediments, the \#Ringstetra values increased offshore, as other reports in shelf sediments (Sinninghe Damsté, 2016). Due to the \#Ringstetra value controlled by $\mathrm{pH}$ (Weijers et al., 2007), we suggest that the low \#Ringstetra values controlled by Changjiang River and Zhe-Min coastal rivers. The high \#Ringstetra values indicated marine in situ brGDGTs on the outer shelf, which was consistent with previous reports results (Duan et al., 2019; Zhang et al., 2020). The IIIa/IIa value was a sensitive source indicator for brGDGTs, and it considerably increased offshore in ECS sediments, which is useful for accurate estimation of organic carbon.

These were also significant differences in the \#Rings $s_{\text {tetra }}$ and IIIa/IIa values between soil and marine derived brGDGTs (Sinninghe Damsté, 2016; Xiao et al., 2016; Crampton-Flood et al., 2018; Warden et al., 2018; Cao et al., 2020; Zhang et al.,
2020; Liu et al., 2021). In marine sediments, the \#Rings tetra $_{\text {values }}$ ranged from 0.79 to 1.12 (avg. 0.96), while the IIIa/IIa values ranged from 0.92 to 1.16 (avg. 1.04), as shown in Figure 4A (Zhou et al., 2014; Sparkes et al., 2015; Xiao et al., 2016; Crampton-Flood et al., 2018; Cao et al., 2020; Zhang et al., 2020; Liu et al., 2021). In Yangtze River Basin soil, the

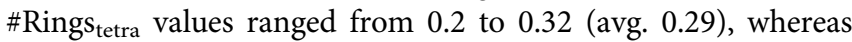
the IIIa/IIa values ranged from 0.22 to 0.45 (avg. 0.35) (Dang et al., 2018). The value of \#Rings $s_{\text {tetra }}$ and IIIa/IIa in Yangtze River Basin soil was lower than that in the surface sediments in ECS (Yang et al., 2014; Dang et al., 2018). Therefore, the existence of marine in situ production of brGDGTs in ECS was shown by the distribution of \#Rings tetra $_{\text {and IIIa/IIa. }}$ and

Thus, the source of brGDGTs is discriminated by the following equations:

$$
\begin{gathered}
\mathrm{A}_{\mathrm{C}}+\mathrm{A}_{\text {marine }}=1 \\
\# \mathrm{R}_{\mathrm{C}} \times \mathrm{A}_{\mathrm{C}}+\# \mathrm{R}_{\text {marine }} \times \mathrm{A}_{\text {marine }}=\# \mathrm{R}_{\text {sample }} \\
\left(\frac{\mathrm{IIIa}}{\mathrm{IIa}}\right)_{\mathrm{C}} \times \mathrm{A}_{\mathrm{C}}+\left(\frac{\mathrm{III} \mathrm{a}}{\mathrm{II}}\right)_{\text {marine }} \times \mathrm{A}_{\text {marine }}=\left(\frac{\mathrm{III} a}{\text { II }}\right)_{\text {sample }}
\end{gathered}
$$

where $A_{C}$ represents the contribution of brGDGTs in the Yangtze River soil, $\mathrm{A}_{\text {marine }}$ represents the contribution of marine in situ production of brGDGTs, $\# \mathrm{R}_{\mathrm{C}}$ represents the mean value of \#Rings $_{\text {tetra }}$ in the Yangtze River catchment soil (a mean of $0.29)$, and $\left(\frac{\mathrm{III} a}{\mathrm{II}}\right)_{\mathrm{C}}$ represents the mean of IIIa/IIa in the Yangtze River catchment soil (a mean of 0.35). Moreover, $\# \mathrm{R}_{\text {marine }}$ and $\left(\frac{\mathrm{III}}{\mathrm{II}}\right)_{\text {marine }}$ are considered as the marine in situ production of brGDGTs in the marine environment, with averages of 0.96 and 1.04, respectively (Zhou et al., 2014; Sparkes et al., 2015; Xiao et al., 2016; Crampton-Flood et al., 2018; Cao et al., 2020; Zhang et al., 2020, Liu et al., 2021). As a result, the contributions of brGDGTs derived from Yangtze River catchment ranged from 34 to $91 \%$ (Figure 4B), while marine in situ production of brGDGTs ranged from 9 to $66 \%$ (Figure 4C). In general, the production of marine in situ brGDGTs in the ECS showed an increasing trend from the coast to the outer shelf. The majority of the soil brGDGTs were deposited in the estuary and coast, which was consistent with previous reports (Duan et al., 2019; Cao et al., 2020; Zhang et al., 2020). 


\section{Implications for Marine In Situ brGDGTs Paleothermometry}

Previous studies suggest that brGDGTs can be produced in situ in the water column or the sediments of an aquatic environment (Peterse et al., 2009; Kim et al., 2012; Sparkes et al., 2015; Sinninghe Damsté., 2016; Xiao et al., 2016; Crampton-Flood et al., 2018; Warden et al., 2018; Cao et al., 2020; Zhang et al., 2020, Liu et al., 2021). Acidobacteria have been proposed as a potential candidate group, and its subdivisions I, III, IV, and VI had produced the presumed building block of brGDGTs (Weijers et al., 2009; Sinninghe Damsté et al., 2018). Compared with the anaerobic zones, Acidobacteria increased from 2.80 to $4.69 \%$ of total bacterial RNA in sediments and increased from 0.05 to $4.91 \%$ in oxygen-saturated areas (Zimmermann et al., 2012). Acidobacteria preferred aerobic zones with an organically enriched environment. In addition, they had a feedback relationship with phototrophic communities dominated by cyanobacteria (Zimmermann et al., 2006; Zimmermann et al., 2012). The differences of methylation and cyclization of brGDGTs in microbial cultures of Acidobacteria were not only considered as physiological responses but also related to compositional changes (Sinninghe Damsté et al., 2018). As shown in Figure 4, the methylation of brGDGTs in ECS was similar to that of the lakes in the catchments when compared with the soils in the Yangtze River catchments. Moreover, in situ brGDGTs synthesis in water is associated with eutrophication and redox stratification. The high proportion of IIIa' in total brGDGTs is a common phenomenon in marine environments, where in situ production of brGDGTs is significant (Xiao et al., 2016). Besides, it is predominantly biosynthesized in the lower part of the oxygenated water column (Weber et al., 2018), which imprints the redox transition zone at the subsurface water in the ocean. In membrane lipid simulations, the decreasing degree of methylation leads to a more ordered and compact membrane with reduced membrane fluidity (Naafs et al., 2021). Therefore, marine in situ brGDGTs are preferred to associate with subsurface water. In recent work, samples by the contribution rate of in situ production of brGDGTs for temperature reconstructions allowed the $\mathrm{MBT}^{\prime}$ 5MEmarine to be separated from samples (Crampton-Floodet al., 2018). Thus, we calculated the $\mathrm{MBT}^{\prime}$ $5 \mathrm{MEmarine}$ in low-latitude continental margin surface sediments and associated with the subsurface water. It showed good potential in paleoenvironment reconstruction and land-sea interactions. Moreover, earlier research had shown that $\mathrm{pH}$ has a significant impact on modifying the degree of cyclization to mix the sources of brGDGTs (De Jonge et al., 2014; Russell et al., 2018a; Naafs et al., 2021). Therefore, the effects of methylation and cyclization on keeping membranes fluid and permeable must be considered in brGDGTs paleothermometers. Overall, brGDGT paleothermometer is worth further research to understand its responses in climate changes.

\section{CONCLUSION}

The spatial distribution and fractional abundance of brGDGTs in ECS were reported in this study. There was also a quantitative source analysis of brGDGTs. The results showed a decreasing trend in total brGDGTs from the estuary and the inner shelf to the outer shelf. The
MAAT based on $\mathrm{MBT}^{\prime} 5 \mathrm{ME}$ at the estuary and the inner shelf matched the recorded air temperature at the Yangtze River mid-lower reaches. Furthermore, the findings indicated mixed sources of soilderived brGDGTs were dominant and showed decreased offset offshore. Meanwhile, due to weak riverine transportation, the outer shelf was dominated by marine in situ brGDGTs, which were characterized by high \#Ringstetra and IIIa/IIa values. Overall, the degree of brGDGT methylation or cyclization is deeply influenced by the environment. Compared with MAAT, marine in situ brGDGT components are more relevant with subsurface water temperature. It is worth noting that there are deviations when employing the relation indicators of brGDGT components to separate land and sea sources in sediments, and much data are required to train the model.

\section{DATA AVAILABILITY STATEMENT}

The raw data supporting the conclusion of this article will be made available by the authors, without undue reservation.

\section{AUTHOR CONTRIBUTIONS}

Conceptualization, RZ and TL; formal analysis, YW, JY, RZ, TL, JR, FZ, YS, XY, JH, JW, XW, ZL, MG and QH; original draft preparation, YW, RZ and TL; and review and editing, RZ and TL. All authors have read and agreed to the published version of the manuscript.

\section{FUNDING}

This work was financed by the National Natural Science Foundation of China (U1906211, 91958108, 42176059, 41830539, 41406055, 41506106, 41230959, 41476043), the Strategic Priority Research Program of the Chinese Academy of Sciences (XDA11030104), the project of Global Change and Air-Sea Interaction, International Postdoctoral Exchange Fellowship Program (20160073), Natural Science Foundation of Jiangsu Province (BK20170451, BE2016701), Six talent peaks project in Jiangsu Province (JNHB-143), “521” talent peaks project in Lianyungang City (LYG52105-2018044, LYG06521202131). We are also grateful to "Qing Lan Project" of Jiangsu Provincial Department of Education and Academic Program Development of Jiangsu Higher Education Institutions.

\section{ACKNOWLEDGMENTS}

We thank Fengming Chang, the Institute of Oceanography, Chinese Academy of Sciences, and Zhifang Xiong, the First Institute of Oceanography, Ministry of Natural Resources of China, for reviewing this study.

\section{SUPPLEMENTARY MATERIAL}

The Supplementary Material for this article can be found online at: https:/www.frontiersin.org/articles/10.3389/feart-2021-796539/ full\#supplementary-material 


\section{REFERENCES}

Blaga, C. I., Reichart, G.-J., Heiri, O., and Sinninghe Damsté, J. S. (2009). Tetraether Membrane Lipid Distributions in Water-Column Particulate Matter and Sediments: a Study of 47 European Lakes along a north-south Transect. J. Paleolimnol. 41, 523-540. doi:10.1007/s10933-008-9242-2

Cao, J., Duan, X., Jin, X., Lian, E., Yin, P., Li, L., et al. (2020). Sedimentary Core brGDGTs in the East China Sea Are Mainly Produced In Situ as Evidenced by Their Similar Distributions with brGDGTs Derived from Intact Polar Lipids. Org. Geochem. 149, 104095. doi:10.1016/j.orggeochem.2020.104095

Coffinet, S., Huguet, A., Williamson, D., Fosse, C., and Derenne, S. (2014). Potential of GDGTs as a Temperature Proxy along an Altitudinal Transect at Mount Rungwe (Tanzania). Org. Geochem. 68, 82-89. doi:10.1016/ j.orggeochem.2014.01.004

Crampton-Flood, E. D., Peterse, F., Munsterman, D., and Sinninghe Damsté, J. S. (2018). Using Tetraether Lipids Archived in North Sea Basin Sediments to Extract North Western European Pliocene continental Air Temperatures. Earth Planet. Sci. Lett. 490, 13-31. doi:10.1016/j.epsl.2018.03.030

Dang, X., Ding, W., Yang, H., Pancost, R. D., Naafs, B. D. A., Xue, J., et al. (2018). Different Temperature Dependence of the Bacterial brGDGT Isomers in 35 Chinese lake Sediments Compared to that in Soils. Org. Geochem. 119, 72-79. doi:10.1016/j.orggeochem.2018.02.008

De Jonge, C., Hopmans, E. C., Stadnitskaia, A., Rijpstra, W. I. C., Hofland, R., Tegelaar, E., et al. (2013). Identification of Novel Penta- and Hexamethylated Branched Glycerol Dialkyl Glycerol Tetraethers in Peat Using HPLC-MS2, GCMS and GC-SMB-MS. Org. Geochem. 54, 78-82. doi:10.1016/ j.orggeochem.2012.10.004

De Jonge, C., Hopmans, E. C., Zell, C. I., Kim, J.-H., Schouten, S., and Sinninghe Damsté, J. S. (2014). Occurrence and Abundance of 6-methyl Branched Glycerol Dialkyl Glycerol Tetraethers in Soils: Implications for Palaeoclimate Reconstruction. Geochim. Cosmochim. Acta 141, 97-112. doi:10.1016/j.gca.2014.06.013

Dong, L., Li, Q. Y., Li, L., and Zhang, C. L. (2014). Glacial-interglacial Contrast in MBT/CBT Proxies in the South China Sea, Implications for marine Production of Branched GDGTs and continental Teleconnection. Org. Geochem. 79, 74-82.

Duan, L., Song, J., Li, X., and Yuan, H. (2019). Glycerol Dialkyl Glycerol Tetraethers Signature in Sediments of the East China Sea and its Implication on marine and continental Climate and Environment Records. Ecol. Indicators 103, 509-519. doi:10.1016/j.ecolind.2019.04.040

Ge, H., Zhang, C. L., Li, J., Versteegh, G. J. M., Hu, B., Zhao, J., et al. (2014). Tetraether Lipids from the Southern Yellow Sea of China: Implications for the Variability of East Asia Winter Monsoon in the Holocene. Org. Geochem. 70, 10-19. doi:10.1016/j.orggeochem.2014.02.011

Ge, H., Zhang, C., Versteegh, G. J. M., ChenChen, L., Fan, D., Dong, L., et al. (2016). Evolution of the East China Sea Sedimentary Environment in the Past $14 \mathrm{Kyr}$ : Insights from Tetraethers-Based Proxies. Sci. China Earth Sci. 59, 927-938. doi:10.1007/s11430-015-5229-9

Hopmans, E. C., Weijers, J. W. H., Schefuß, E., Herfort, L., Sinninghe Damsté, J. S., and Schouten, S. (2004). A Novel Proxy for Terrestrial Organic Matter in Sediments Based on Branched and Isoprenoid Tetraether Lipids. Earth Planet. Sci. Lett. 224, 107-116. doi:10.1016/j.epsl.2004.05.012

Hopmans, E. C., Schouten, S., and Sinninghe Damsté, J. S. (2016). The Effect of Improved Chromatography on GDGT-Based Palaeoproxies. Org. Geochem. 93, 1-6. doi:10.1016/j.orggeochem.2015.12.006

Huguet, C., Hopmans, E. C., Febo-Ayala, W., Thompson, D. H., Sinninghe Damsté, J. S., and Schouten, S. (2006). An Improved Method to Determine the Absolute Abundance of Glycerol Dibiphytanyl Glycerol Tetraether Lipids. Org. Geochem. 37, 1036-1041. doi:10.1016/j.orggeochem.2006.05.008

Kim, J.-H., Zell, C., Moreira-Turcq, P., Pérez, M. A. P., Abril, G., Mortillaro, J.-M., et al. (2012). Tracing Soil Organic Carbon in the Lower Amazon River and its Tributaries Using GDGT Distributions and Bulk Organic Matter Properties. Geochim. Cosmochim. Acta 90, 163-180. doi:10.1016/j.gca.2012.05.014

Li, Z., Peterse, F., Wu, Y., Bao, H., Eglinton, T. I., and Zhang, J. (2015). Sources of Organic Matter in Changjiang (Yangtze River) Bed Sediments: Preliminary Insights from Organic Geochemical Proxies. Org. Geochem. 85, 11-21. doi:10.1016/j.orggeochem.2015.04.006

Liu, J. P., Li, A. C., Xu, K. H., Velozzi, D. M., Yang, Z. S., Milliman, J. D., et al. (2006). Sedimentary Features of the Yangtze River-Derived Along-Shelf
Clinoform deposit in the East China Sea. Continental Shelf Res. 26, 2141-2156. doi:10.1016/j.csr.2006.07.013

Liu, X., Li, A., Dong, J., Lu, J., Huang, J., and Wan, S. (2018). Provenance Discrimination of Sediments in the Zhejiang-Fujian Mud belt, East China Sea: Implications for the Development of the Mud Depocenter. J. Asian Earth Sci. 151, 1-15. doi:10.1016/j.jseaes.2017.10.017

Liu, Y., Xiao, W., Wu, J., Han, L., Zhang, H., and Xu, Y. (2021). Source, Composition, and Distributional Pattern of Branched Tetraethers in Sediments of Northern Chinese Marginal Seas. Org. Geochem. 157, 104244. doi:10.1016/j.orggeochem.2021.104244

Martínez-Sosa, P., Tierney, J. E., and Meredith, L. K. (2020). Controlled Lacustrine Microcosms Show a brGDGT Response to Environmental Perturbations. Org. Geochem. 145, 104041. doi:10.1016/j.orggeochem.2020.104041

Naafs, B. D. A., Oliveira, A. S. F., and Mulholland, A. J. (2021). Molecular Dynamics Simulations Support the Hypothesis that the brGDGT Paleothermometer Is Based on Homeoviscous Adaptation. Geochim. Cosmochim. Acta 312, 44-56. doi:10.1016/j.gca.2021.07.034

Peterse, F., Kim, J.-H., Schouten, S., Kristensen, D. K., Koç, N., and Sinninghe Damsté, J. S. (2009). Constraints on the Application of the MBT/CBT Palaeothermometer at High Latitude Environments (Svalbard, Norway). Org. Geochem. 40, 692-699. doi:10.1016/j.orggeochem.2009.03.004

Russell, J. M., Hopmans, E. C., Loomis, S. E., Liang, J., and Sinninghe Damsté, J. S. (2018a). Distributions of 5- and 6-methyl Branched Glycerol Dialkyl Glycerol Tetraethers (brGDGTs) in East African lake Sediment: Effects of Temperature, $\mathrm{pH}$, and New Lacustrine Paleotemperature Calibrations. Org. Geochem. 117, 56-69. doi:10.1016/j.orggeochem.2017.12.003

Russell, J. M., Hopmans, E. C., Loomis, S. E., Liang, J., and Sinninghe Damsté, J. S. (2018b). Corrigendum to "Distributions of 5- and 6-methyl Branched Glycerol Dialkyl Glycerol Tetraethers (brGDGTs) in East African lake Sediment: Effects of Temperature, $\mathrm{pH}$, and New Lacustrine Paleotemperature Calibrations" [Org. Geochem. 117 (2018) 56-69]. Org. Geochem. 125, 299. doi:10.1016/ j.orggeochem.2018.08.007

Sinninghe Damsté, J. S. (2016). Spatial Heterogeneity of Sources of Branched Tetraethers in Shelf Systems, the Geochemistry of Tetraethers in the Berau River delta (Kalimantan, Indonesia). Geochim. Cosmochim. Acta 186, 13-31. doi:10.1016/j.gca.2016.04.033

Sinninghe Damsté, J. S., Rijpstra, W. I. C., Foesel, B. U., Huber, K., Overmann, J., Nakagawa, S., et al. (2018). An Overview of the Occurrence of Ether- and EsterLinked Iso-Diabolic Acid Membrane Lipids in Microbial Cultures of the Acidobacteria, Implications for brGDGT Paleoproxies for Temperature and pH. Org. Geochem. 124, 63-76. doi:10.1016/j.orggeochem.2018.07.006

Sparkes, R. B., Doğrul Selver, A., Bischoff, J., Talbot, H. M., Gustafsson, Ö., Semiletov, I. P., et al. (2015). GDGT Distributions on the East Siberian Arctic Shelf: Implications for Organic Carbon export, Burial and Degradation. Biogeosciences 12, 3753-3768. doi:10.5194/bg-12-3753-2015

Warden, L., Moros, M., Weber, Y., and Sinninghe Damsté, J. S. (2018). Change in Provenance of Branched Glycerol Dialkyl Glycerol Tetraethers over the Holocene in the Baltic Sea and its Impact on continental Climate Reconstruction. Org. Geochem. 121, 138-154. doi:10.1016/j.orggeochem.2018.03.007

Weber, Y., Sinninghe Damsté, J. S., Zopfi, J., De Jonge, C., Gilli, A., Schubert, C. J., et al. (2018). Redox-dependent Niche Differentiation Provides Evidence for Multiple Bacterial Sources of Glycerol Tetraether Lipids in Lakes. Proc. Natl. Acad. Sci. USA 115, 10926-10931. doi:10.1073/pnas.1805186115

Weijers, J. W. H., Schouten, S., van den Donker, J. C., Hopmans, E. C., and Sinninghe Damsté, J. S. (2007). Environmental Controls on Bacterial Tetraether Membrane Lipid Distribution in Soils. Geochim. Cosmochim. Acta 71, 703-713. doi:10.1016/j.gca.2006.10.003

Weijers, J. W. H., Panoto, E., van Bleijswijk, J., Schouten, S., Rijpstra, W. I. C., Balk, M., et al. (2009). Constraints on the Biological Source(s) of the Orphan Branched Tetraether Membrane Lipids. Geomicrobiol. J. 26, 402-414. doi:10.1080/01490450902937293

Wu, Y., Zhang, J., Li, D. J., Wei, H., and Lu, R. X. (2003). Isotope Variability of Particulate Organic Matter at the PN Section in the East China Sea. Biogeochemistry 65, 31-49. doi:10.1023/a:1026044324643

Xiao, W., Wang, Y., Zhou, S., Yang, L. H., Yang, H., and Xu, Y. (2016). Ubiquitous Production of Branched Glycerol Dialkyl Glycerol Tetraethers (brGDGTs) in Global marine Environments: a New Source Indicator for brGDGTs. Biogeosciences 13, 5883-5894. doi:10.5194/bg-13-5883-2016 
Xie, S., Pancost, R. D., Chen, L., Evershed, R. P., Yang, H., Zhang, K., et al. (2012). Microbial Lipid Records of Highly Alkaline Deposits and Enhanced Aridity Associated with Significant Uplift of the Tibetan Plateau in the Late Miocene. Geology 40, 291-294. doi:10.1130/g32570.1

Yamamoto, Y., Ajioka, T., and Yamamoto, M. (2016). Climate Reconstruction Based on GDGT-Based Proxies in a Paleosol Sequence in Japan: Postdepositional Effect on the Estimation of Air Temperature. Quat. Int. 397, 380-391. doi:10.1016/j.quaint.2014.12.009

Yang, H., Pancost, R. D., Dang, X., Zhou, X., Evershed, R. P., Xiao, G., et al. (2014). Correlations between Microbial Tetraether Lipids and Environmental Variables in Chinese Soils: Optimizing the Paleo-Reconstructions in Semi-arid and Arid Regions. Geochim. Cosmochim. Acta 126, 49-69. doi:10.1016/j.gca.2013.10.041

Zell, C., Kim, J.-H., Hollander, D., Lorenzoni, L., BakerSilva, P. C. G., Silva, C. G., et al. (2014). Sources and Distributions of Branched and Isoprenoid Tetraether Lipids on the Amazon Shelf and Fan: Implications for the Use of GDGT-Based Proxies in marine Sediments. Geochim. Cosmochim. Acta 139, 293-312. doi:10.1016/j.gca.2014.04.038

Zhang, R., Li, T., Russell, J., Zhou, Y., Zhang, F., Liu, Z., et al. (2018). Highresolution Reconstruction of Historical Flood Events in the Changjiang River Catchment Based on Geochemical and Biomarker Records. Chem. Geol. 499, 58-70. doi:10.1016/j.chemgeo.2018.09.003

Zhang, J., Yu, Z., and Jia, G. (2020). Cyclisation Degree of Tetramethylated brGDGTs in marine Environments and its Implication for Source Identification. Glob. Planet. Change 184, 103043. doi:10.1016/ j.gloplacha.2019.103043

Zhou, H., Hu, J., Spiro, B., Peng, P. a., and Tang, J. (2014). Glycerol Dialkyl Glycerol Tetraethers in Surficial Coastal and Open marine Sediments Around China: Indicators of Sea Surface Temperature and Effects of Their Sources. Palaeogeogr. Palaeoclimatol. Palaeoecol. 395, 114-121. doi:10.1016/j.palaeo.2013.12.006
Zhu, C., Weijers, J. W. H., Wagner, T., Pan, J.-M., Chen, J.-F., and Pancost, R. D. (2011). Sources and Distributions of Tetraether Lipids in Surface Sediments across a Large River-Dominated continental Margin. Org. Geochem. 42, 376-386. doi:10.1016/j.orggeochem.2011.02.002

Zimmermann, J., Gonzalez, J. M., and Saiz-Jimenez, C. (2006). Epilithic Biofilms in Saint Callixtus Catacombs (Rome) Harbour a Broad Spectrum of Acidobacteria. Antonie van Leeuwenhoek 89, 203-208. doi:10.1007/s10482005-9020-3

Zimmermann, J., Portillo, M. C., Serrano, L., Ludwig, W., and Gonzalez, J. M. (2012). Acidobacteria in Freshwater Ponds at Doñana National Park, Spain. Microb. Ecol. 63, 844-855. doi:10.1007/s00248-011-9988-3

Conflict of Interest: The authors declare that the research was conducted in the absence of any commercial or financial relationships that could be construed as a potential conflict of interest.

Publisher's Note: All claims expressed in this article are solely those of the authors and do not necessarily represent those of their affiliated organizations, or those of the publisher, the editors, and the reviewers. Any product that may be evaluated in this article, or claim that may be made by its manufacturer, is not guaranteed or endorsed by the publisher.

Copyright (c) 2022 Wang, Yang, Wang, Zhang, Zhang, Li, Russell, Wang, Wang, Zhang, Song, Yu, Hu, Liu, Guan and Han. This is an open-access article distributed under the terms of the Creative Commons Attribution License (CC BY). The use, distribution or reproduction in other forums is permitted, provided the original author(s) and the copyright owner(s) are credited and that the original publication in this journal is cited, in accordance with accepted academic practice. No use, distribution or reproduction is permitted which does not comply with these terms. 